fournal of Medical Genetics (1973). 10, 350.

\title{
Fluorescence and Autoradiographic Studies in Patients with Turner's Syndrome and 46,XXp- and 46,XXq- Karyotypes
}

\author{
K. BOCZKOWSKI and MARGARETA MIKKELSEN \\ Division of Genetics, Institute of Obstetrics and Gynaecology, Medical Academy in Warsaw, Poland and the fohn \\ F. Kennedy Institute, Glostrup, Denmark
}

Summary. Two patients with the clinical picture of Turner's syndrome showed a $46, \mathrm{XXp}$ - and a $46, \mathrm{XXq}$ - karyotype identified by a combination of fluorescence and autoradiography. Autoradiography showed that the abnormal X chromosome was indicated in most cells. The $\mathrm{Xg}$ findings in case 1 indicated that the abnormal $\mathrm{X}$ chromosome was of paternal origin.

Patients with deletions of the short or long arm of the $\mathrm{X}$ chromosome might give information about the relationship of specific chromosomal material to the multiple stigmata encountered in Turner's syndrome. Ferguson-Smith (1965) and Jacobs (1969) suggested that genes present on the long and the short arms of both $\mathrm{X}$ chromosomes are necessary for the development of a functioning ovary, because in $46, \mathrm{XXp}-$ and $46, \mathrm{XXq}$ - females the normal ovaries are replaced by streak gonads. However, the shortness of stature and the other somatic abnormalities frequently associated with a $45, \mathrm{X}$ complement are not present in females with a $46, \mathrm{XXpi}$ or $46, \mathrm{XXq}$ - complement, but are present in those with a $46, \mathrm{XXqi}$ or $46, \mathrm{XXp}$ - complement. They suggested, therefore, that genes apparently influential on the development of stature, and of the other somatic features which are frequently abnormal in females with a $45, \mathrm{X}$ complement, are situated on the short arm of the $X$ chromosome.

However, Hecht et al (1970) and Bocian et al (1971) have recently challenged this concept and have presented data indicating that the somatic stigmata of Turner's habitus, including short stature, can occur in cases with deletion of the long arm, as it does in deletion of the short arm of the X chromosome.

We shall report two patients with Turner's syndrome, one with a $46, \times X p$ - and the other with a 46,XXq - karyotype.

Received 7 June 1973.

\section{Case 1}

Case Report. The patient, P.E. (241053), was the third of four girls born after an uncomplicated pregnancy. Her mother was 34 and her father 39 years of age at her birth. Nothing is known about parental radiation exposure. Her sibs are healthy. She was first seen at age 16 years because of short stature $(130 \mathrm{~cm})$. She was always shorter than other children. No spontaneous menstruation had occurred. Her chest was barrelshaped, with widely separated nipples, no breast development, and her neck was short with slight webbing (Fig. 1). The pubic hair was scanty, and the external genitalia were infantile. The labia minora were rudimentary and developed only in the upper third. The uterus was infantile. Twenty-four hour urinary gonadotrophin level was elevated. No laparotomy was performed.

Cytogenetic Studies. Sex-chromatin staining showed $14 \%$ Barr bodies, no fluorescent $Y$ bodies were present. Chromosome analysis was performed in Warsaw according to the method of Moorhead et al (1960). Thirty cells were counted, six were analysed in detail from enlarged microphotograph. A 46,XXp - karyotype was diagnosed.

Blood and skin was mailed to the Kennedy Institute in Denmark. Skin was cultured using the method described by Therkelsen (1964). Twentyfive cells were examined; all had a $46, \mathrm{XXp}-$ karyotype. Blood was cultured in the usual way for 48 hours under addition of phytohaemagglutinin. To one culture ${ }^{3} \mathrm{H}$-thymidine $(1.0 \mu \mathrm{c} / \mathrm{ml}$ cell suspension) was added $4 \frac{1}{2}$ hours before harvesting. Colcemid was added $2 \frac{1}{2}$ hours before harvesting. Air-dried slides prepared without heating were 
stained with quinacrine mustard using a modification of the method of Caspersson et al (1970). Thirty cells were examined and microphotographed on a Leitz Orthoplan microscope fitted with a HBO 200 vertical illuminator. The ${ }^{3} \mathrm{H}$-labelled slides were destained and restained with Orcein, the others with Giemsa. The Orcein-stained slides were covered with Ilford $\mathrm{K} 2$ emulsion, exposed for 10 days and developed with amidol. Sixteen cells were examined by fluorescence and autoradiography. The $\mathrm{Xp}$ - chromosome was easily identified by fluorescence. It was late labelling in 13 cells (Fig. 2 ), three cells were unlabelled or unsuitable. Fourteen cells were examined by fluorescence and Giemsa staining; all showed a $46, \mathrm{XXp}$ - karyotype, the breakpoint being at p11, near to the centromere. The karyotype is therefore $46, \mathrm{X}, \operatorname{del}(\mathrm{X})$ (p11 $\rightarrow$ qter) (Paris Conference, 1971).

The Xg blood groups in this family were studied by Dr R. R. Race and Dr R. Sanger. The mother and the girl were $\mathrm{Xg}(\mathrm{a}-)$, while the father was $\mathrm{Xg}(\mathrm{a}+)$.



FIG. 1. Case 1 at the age of 16 years.

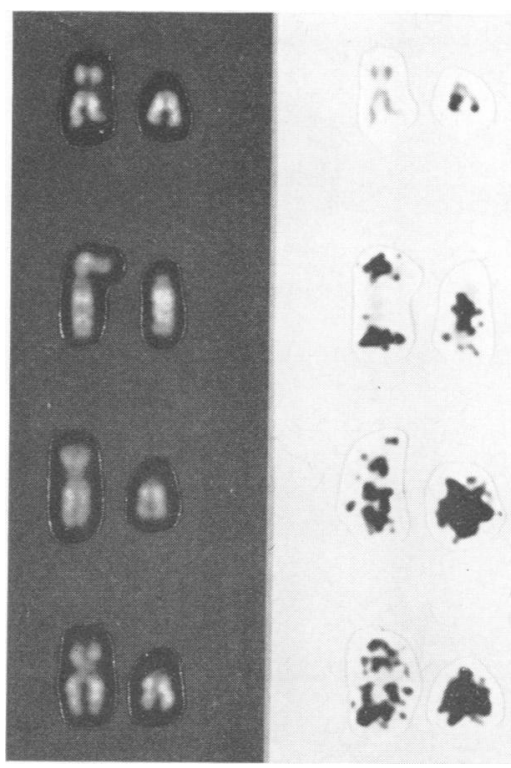

FIG. 2. Fluorescence and autoradiography of $\mathrm{X}$ and $\mathrm{Xp}$ - chromosomes from four cells with different degrees of ${ }^{3} \mathrm{H}$-thymidine labelling.

\section{Case 2}

Case Report. The patient, M.G. (131149), was born as the second of four sibs. Her mother was 25 and her father 29 years old at her birth. The pregnancy was uncomplicated. There was no parental exposure to radiation. An older sister and two younger brothers are healthy. She was first seen because of short stature (145 $\mathrm{cm}$ at the age 21) and primary amenorrhoea. The girl was always shorter than other children. Her chest was barrel-shaped, with widely separated nipples, and her neck was shorter without webbing (Fig. 3). Slight breast development occurred after hormonal treatment. The pubic hair was scanty, and the external genitalia were infantile. The labia minora were rudimentary and developed only in the upper third. Twenty-four hour urinary gonadotrophin level was elevated. No laparotomy was performed.

Radiological studies of her hands revealed a shortening of the fourth and fifth metacarpals and positive metacarpal sign. The graphical picture of the knee joints revealed flattening of the tibial heads with beak-like deformities of the medial tibial condyles (Fig. 4).

Cytogenetic Studies. In buccal mucosa neither Barr bodies nor fluorescent $\mathrm{Y}$ bodies were present. Autoradiographic and fluorescence studies were performed in the same way as in case 1 .

Fourteen cells were examined by fluorescence and autoradiography. In 11 cells at least the short arm of the deleted $X$ was later labelling than the normal one (Fig. 5), one cell showed the Xqchromosome early labelling and the normal $\mathrm{X}$ late 


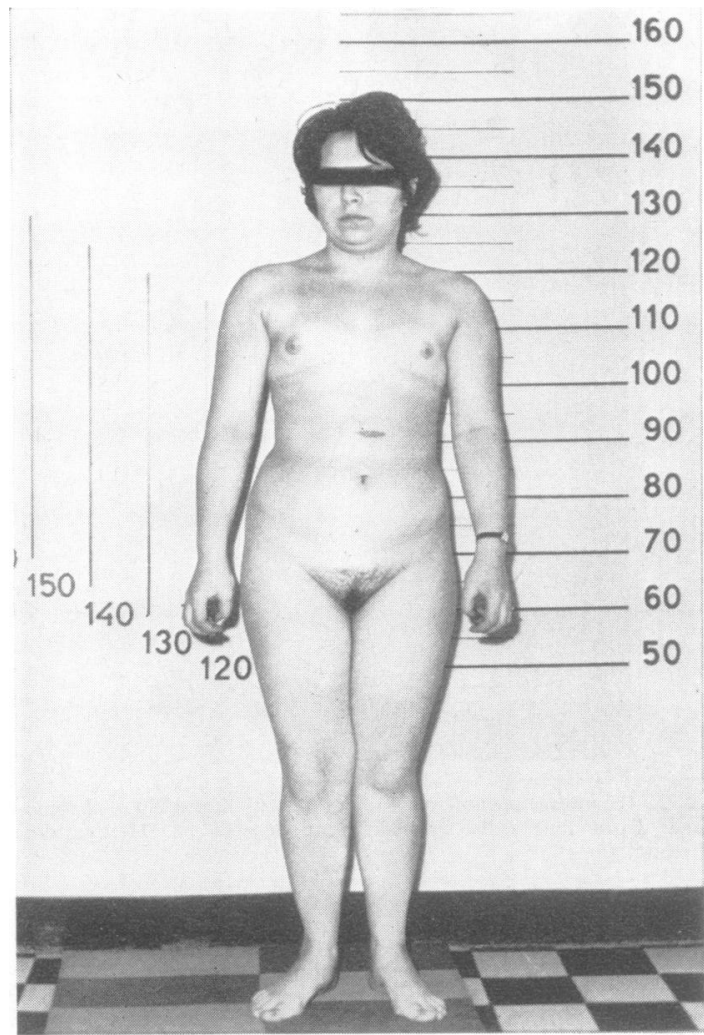

Fig. 3. Case 2 at the age of 23 years.



FIG. 4. $X$-ray of knee joints from case 2. Note flattening of tibial heads and deformity of medial tibial condyles.

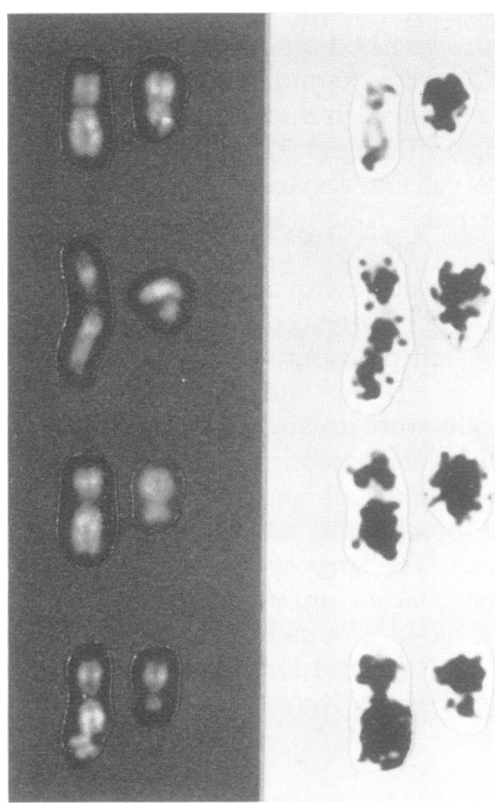

FIG. 5. Fluorescence and autoradiography of $\mathbf{X}$ and $\mathrm{Xq}-$ chromosomes from four cells with different degrees of ${ }^{3} \mathrm{H}$-thymidine labelling. Note breakage and late-labelling patterns of the long arm of the normal $X$ in cell 4 .

labelling (Fig. 6); two cells were unlabelled. Seven cells were studied autoradiographically only; allo showed a very hot chromosome of the size of the? deleted X. Sixteen cells were studied by fluorescence and Giemsa staining. The break-point was at q21, the karyotype being $46, \mathrm{X}, \mathrm{del}(\mathrm{X})$ (pter $\rightarrow \mathrm{q} 21$ ) (Paris Conference, 1971).

The $\mathrm{Xg}$ groups of this patient and her parents were not examined because her father could not be traced.

\section{Discussion}

General medical examination, gynaecological examination, and radiological studies of these two cases showed abnormalities characteristic of Turner's syndrome. These two patients indicate that the characteristic feature of Turner's phenotype can be present in cases with deletion of the short arm of the $\mathrm{X}$ chromosome, as well as in cases with deletion of the long arm.

The problem arises whether these abnormalities could be related to the lack of genes located on the deleted part of the $\mathrm{X}$ chromosome or the lack of influence from the heterochromatic $\mathbf{X}$ chromosome considered en bloc.

The fact that short stature was present in the case with a deletion of the short arm of the $\mathrm{X}$ as well as in the case with a deletion of the long arm of the $X$ 


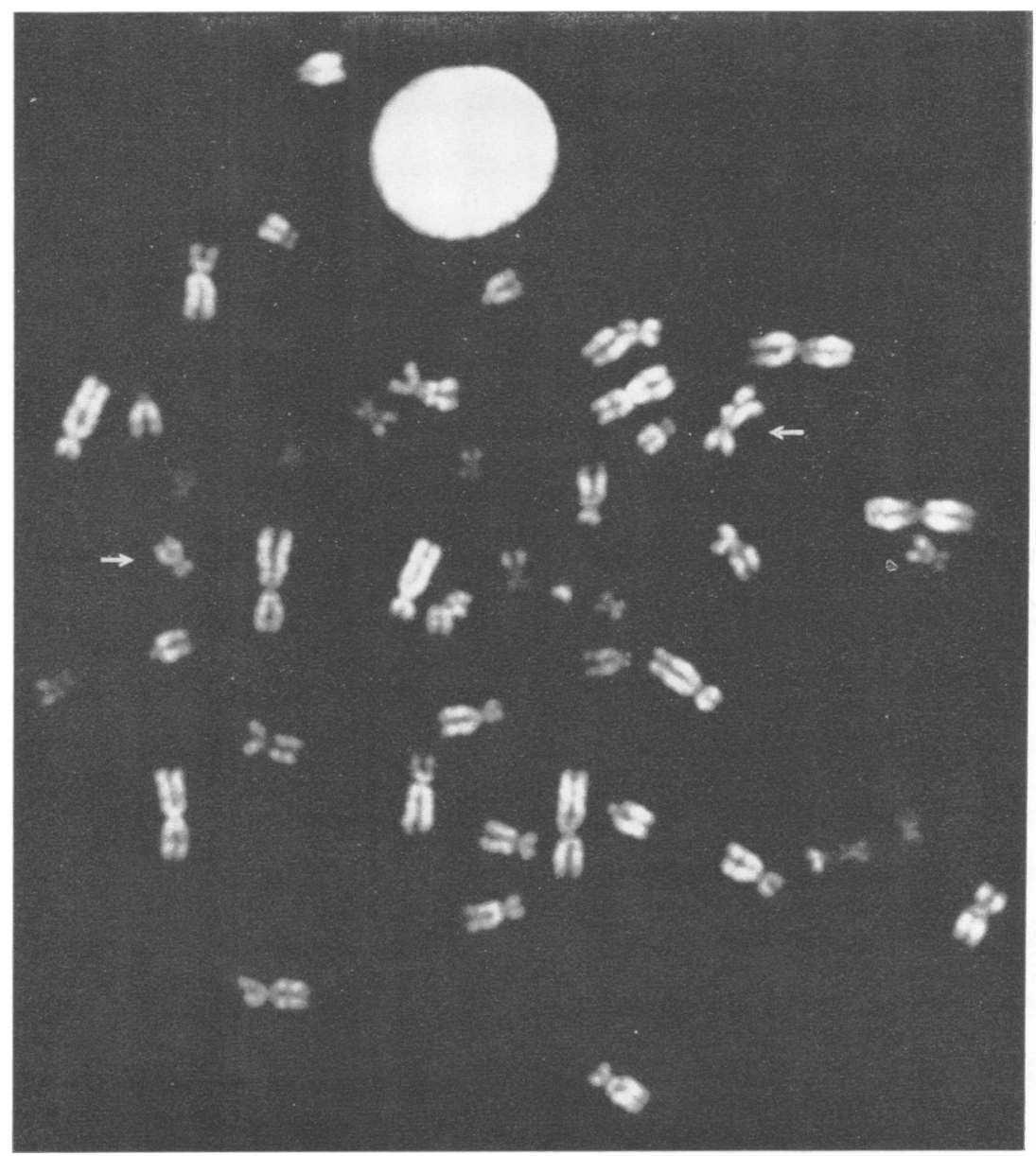

FIG. 6a. Cell (see Fig. 5) with fluorescence and ${ }^{3} \mathrm{H}$-thymidine labelling.

chromosome, does not decisively speak in favour of the first possibility because, it could be argued, that the joint action of genes present both on the short and the long arms of the $\mathrm{X}$ chromosome is necessary for normal development of stature.

From our studies it is apparent, however, that in most cells the abnormal $\mathrm{X}$ chromosome was inactive. Therefore it could be assumed that in our cases, there was a lack of genetic information from the heterochromatic $\mathrm{X}$ chromosome, but not from the euchromatic $X$. Therefore, the second explanation seems to be more probable. Of course, we cannot completely rule out the possibility that some genes are not inactivated on the apparently heteromatic inactive $\mathrm{X}$ chromosome, or that the action of genes related with stature is exerted during the early embryonal period, before their inactivation.

The combination of fluorescence and autoradiography made it possible to identify both the normal and the abnormal $\mathbf{X}$ chromosomes and to study their behaviour. In one cell only (in case 2), the abnormal $\mathrm{X}$ was early labelling while the normal $\mathrm{X}$ was late labelling. In all the other informative cells, the abnormal $\mathrm{X}$ chromosome was inactive. This is a deviation from the random inactivation of $\mathrm{X}$ chromosomes (Lyon, 1961), but is in accordance with the findings in other cases of $\mathrm{X}$-chromosome deletion (Fraccaro and Lindsten, 1964; Atkins, Santesson, and Voss, 1965; Steinberger et al, 1966; Giannelli, 1970; Kikuchi and Oishi, 1970) and 


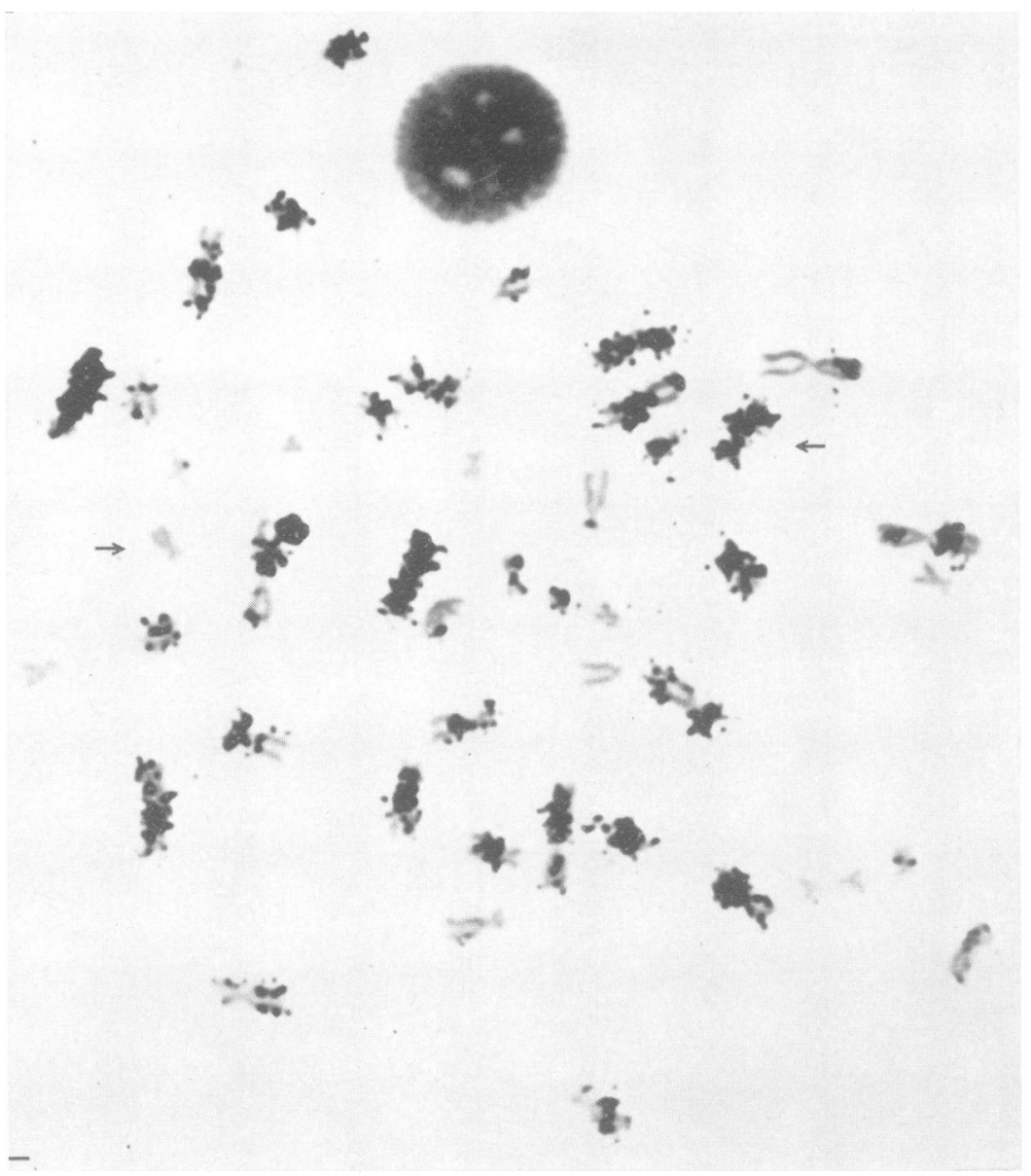

Fig. 6b. The same cell as Fig. 6a. Note the unlabelled Xq- chromosome (arrows).

different from the behaviour of abnormal X chromosomes in X-autosomal translocations (Allderdice et al, 1971; Buckton et al, 1971; Mikkelsen and Dahl, 1973).

The $\mathrm{Xg}$ findings in case 1 and in her mother, where both were $\mathrm{Xg}(\mathrm{a}-)$ while the father was $\mathrm{Xg}(\mathrm{a}+)$, indicate that the child has inherited the normal $\mathrm{X}$ chromosome from her mother while the abnormal $\mathrm{X}$ was of paternal origin and may have originated in the gametogenesis of the father, as no sign of mosaicism was found.

Lindsten et al (1963) suggested that the locus controlling the $\mathrm{Xg}$ blood groups is located on the short arm of the $X$. They based their hypothesis on two cases of isochromosome for the long arm of the $\mathrm{X}$, where the patients were $\operatorname{Xg}\left(\mathrm{a}_{-}\right)$but their fathers were $\mathrm{Xg}(\mathrm{a}+)$. Polani et al (1970) however, also found exceptional $\mathrm{Xg}(\mathrm{a}-)$ daughters of $\mathrm{Xg}(\mathrm{a}+)$ fathers in cases with long arm deletions of the $X$. Furthermore, the frequency of $\mathrm{Xg}(\mathrm{a}-)$ among these women was male and not female. These findings together with the preferential late-labelling pattern of the abnormal $\mathrm{X}$ give evidence that the $\mathrm{Xg}$ locus is inactivated in structurally abnormal $\mathrm{X}$ chromosomes. In structurally normal $\mathrm{Xs}$, the $\mathrm{Xg}$ locus seems to escape inactivation (Ducos et al, 1971). Unfortunately it was not possible to examine the $\mathrm{Xg}$ groups of the $\mathrm{Xq}-$ case and her parents which would have been of great interest, as an $\mathrm{Xg}(\mathrm{a}-)$ type from an $\mathrm{Xg}(\mathrm{a}+)$ father would have given strong support to Polani et al's hypothesis of inactivation of the Xg locus in structural abnormal X chromosomes. 
We are grateful to Dr R. R. Race and Dr Ruth Sanger for $\mathrm{Xg}$ studies and fruitful discussion. The expert technical assistance of Mrs Hanne Poulsen is greatfully acknowledged. This work was supported by grants from the Danish Medical Research Council and the Danish National Board of Social Welfare.

\section{REFERENCES}

Allderdice, P. W., Miller, O. J., Klinger, H. P., Pallister, P. D., and Opitz, J. M. (1971). Demonstration of a Spreading Effect in an $X$-autosome Translocation by Combined Autoradiographic and Quinacrine-flourescence Studies. Excerpta Medica, International Congress Series No. 233, pp. 14-15, Amsterdam.

Atkins, L., Santesson, B., and Voss, H. (1965). Partial deletion of an $\mathrm{X}$ chromosome. Annals of Human Genetics, 29, 89-95.

Bocian, M., Krmpotoc, E., Szego, K., and Rosenthal, I. M. (1971). Somatic stigmata of Turner's syndrome in a patient with 46,XXq - . Fournal of Medical Genetics, 8, 358-363.

Buckton, K. E., Jacobs, P. A., Rae, L. A., and Newton, M. S. (1971). An inherited X-autosome translocation in man. Annals of Human Genetics, 35, 171-178.

Caspersson, T., Zech, L., Johansson, C., and Modest, E. J. (1970). Identification of human chromosomes by DNA-binding fluorescent agents. Chromosoma, 30, 215-227.

Ducos, J., Marty, Y., Sanger, R., and Race, R. R. (1971). Xg and $\mathrm{X}$ chromosome inactivation. Lancet, 2, 219-220.

Ferguson-Smith, M. A. (1965). Karyotype-phenotype correlations in gonadal dysgenesis and their bearing on the pathogenesis of malformations. Fournal of Medical Genetics, 2, 142-155.

Fraccaro, M. and Lindsten, J. (1964). The nature, origin, and genetic implications of structural abnormalities of the sex chromosomes in man. In Cytugenetics of Cells in Culture, ed. by R. J. C. Harris, ch. 3, pp. 97-110. Academic Press, London and New York.
Giannelli, F. (1970). Human Chromosomes DNA Synthesis, ch. 5, pp. 38-49. Karger, Basel, Munich, and New York.

Hecht, F., Jones, D. L., Delay, M., and Klevit, H. (1970). Xq Turner's syndrome: reconstruction of hypothesis that $\mathrm{Xp}-$ causes somatic features in Turner's syndrome. Fournal of Medical Genetics, 7, 1-4.

Jacobs, P. A. (1969). Structural abnormalities of the sex chromosomes. British Medical Bulletin, 25, 94-98.

Kikuchi, Y. and Oishi, H. (1970). Internal asynchrony in late replication of human $\mathrm{X}$ chromosomes with structural abnormalities. Fapanese fournal of Human Genetics, 15, 114-123.

Lindsten, J., Fraccaro, M., Polani, P. E., Hamerton, J. L., Sanger, R., and Race, R. R. (1963). Evidence that the Xg blood group genes are on the short arm of the $\mathrm{X}$ chromosome. Nature, 197, 648-649.

Lyon, M. F. (1961). Gene action in the X-chromosome of the mouse (Mus musculus L.). Nature, 190, 372-373.

Mikkelsen, M. and Dahl, G. (1973). Unbalanced X autosomal translocation with inactivation of normal $\mathrm{X}$ chromosome. Cytogenetics. (In press.)

Moorhead, P. S., Nowell, P. C., Mellman, W. J., Battipps, D. M., and Hungerford, D. A. (1960). Chromosome preparations of leukocyte cultured from human peripheral blood. Experimental Cell Research, 20, 613-615.

Paris Conference (1971). Standardization in human cytogenetics. Birth Defects: Original Article Series, 8, pt. 7, 1972. The National Foundation-March of Dimes, New York.

Polani, P. E., Angell, R., Giannelli, F., Chapelle, A., de la, Race, R. R., and Sanger, R. (1970). Evidence that the $\mathrm{Xg}$ locus is inactivated in structurally abnormal X chromosomes. Nature, 227, 613-616.

Steinberger, E., Steinberger, A., Smith, K. D., and Perloff, W. H. (1966). Apparent deletion of X chromosome in a prepuberal girl. fournal of Medical Genetics, 3, 226-229.

Therkelsen, A. J. (1964). 'Sandwich' technique for the establishment of cultures of human skin for chromosome investigation. Acta pathologica et microbiologica Scandinavica, 61, 317. 